\title{
Is the secret to effective lifelong learning lurking in the views of prospective kindergarten teachers? Comparing German and Hungarian prospective kindergarten teachers' views on learning
}

Nikolett Flick-Takács

\begin{abstract}
Lifelong learning (LLL) became a basis for education policies in the 21 st century. The GLLI (Global Lifelong Learning Index) ranks countries based on their performance in LLL (Kim, 2016). The present paper aims to compare a successful country (Germany) with a mid-performing country (Hungary) in two ways: (1) by comparing the two countries' framework strategies and training requirements for lifelong learning, and (2) by comparing prospective views on learning in Hungarian $\left(\mathrm{N}_{\mathrm{H}}=14\right)$ and German $\left(\mathrm{N}_{\mathrm{G}}=14\right.$;) kindergarten student teacher groups using Verges' association matrices in order to identify the key LLL elements in their views. The target group for the qualitative research was selected based on the pedagogical phenomenon that the views of prospective teachers have a great impact on their later work, including in relation to child development (Ránki, 2002; Dudás, 2005; Takács, 2016). The results show that there are some differences in the interpretation of LLL between the two countries, which can be observed in the regulatory documents and the associations made by student kindergarten teachers. The results reveal differences in the importance of self-regulated learning, learning motivation and social competences, and some common elements, like playfulness or joy, in learning activities.
\end{abstract}

Keywords: qualitative study, prospective teachers, views about learning, associations 


\section{Introduction}

The importance of lifelong learning is now indisputable, not just in educational policy documents, but also in practice. Since Lifelong Learning for All (OECD, 1996) and the Delors Report (UNESCO, 1996) were published, lifelong learning has become increasingly widespread across the world and in EU member states. As a result, around the turn of the millennium, EU member states developed their own education policies and frameworks to support lifelong learning in line with EU objectives (Hungarian Government, 2014; Bund-Länder-Kommission, 2004).

As in many other areas, there are between-country differences in performance and interpretations of the effectiveness of lifelong learning (LLL). The aim of this study is to show that interpretations of lifelong learning may differ in a successful and a moderately well-performing country (Table 1). The present study is based on the results of an international survey (Global Lifelong Learning Index; GLLI) and compares a successful country (Germany) and a mid-performing country (Hungary) in two ways: (1) by comparing the two countries' framework strategies and training requirements for lifelong learning (Q1-2), and (2) by comparing prospective kindergarten teachers' views on learning between a Hungarian $\left(\mathrm{N}_{\mathrm{H}}=14\right)$ and a German $\left(\mathrm{N}_{\mathrm{G}}=14\right.$;) student group using Verges' association matrices in order to identify the key LLL elements in their views (Q3-4) (Table 1).

As the differences between the countries identified by the GLLI were the basis for this research, a more detailed description of Kim's (2016) study will be provided in a later part of this paper. The two chosen countries (Hungary and Germany) perform significantly differently in LLL and their TALIS results show that the effectiveness of a nation's education is determined by its educators. Therefore, a good starting point for exploring this topic is to conduct action research examining whether there are any differences in prospective kindergarten teachers' views (Ben et. al., 2012).

The qualitative comparison was based on the pedagogical fact that the views of prospective teachers greatly influence their work, including child development (Ránki, 2002; Dudás, 2005; Hercz, 2013; Takács, 2016). Kindergarten teachers play an important role in laying the foundations for lifelong learning at the very first level of public education (Kariciné, 2004). For these reasons, we assume it is possible to observe different approaches to lifelong learning in the views of German and Hungarian kindergarten student teachers. 
Table 1 Aim and methods of the study



The present study compares the views of 14 Hungarian and 14 German kindergarten student teachers on kindergarten and primary school learning using a qualitative associative method, applying the Vergés association matrix (Vergés, 1994 In: Sándor, 2009). Given the different education systems in the two countries and their LLL (GLLI) rankings (Germany: 12th; Hungary: 39th), it can be assumed that both the document analysis and results of the qualitative association method will reveal differences between the two countries. These may take us a step closer to identifying why Germany is more successful in providing lifelong learning.

\section{Characteristics and Models of the Early Stage of Lifelong Learning}

Although the lifelong learning (LLL) paradigm is not a new concept in national and international education policy trends, the early phase of this 
process attracts significantly less international research (Aspin, Chapman, 2000). According to the regulatory documents, the early phase of LLL takes place between approximately three and twelve years of age (Majzik, 1997; Hungarian Government 2005).

The function of kindergarten and primary education - but especially primary school education - is set out in national and international documents guiding the educational process. Only a few of these documents discuss the lifelong learning educational goals from kindergarten age. Based on the OECD series about good practices in supporting lifelong learning, Júlia Ránki Lantos (2002) highlights some common points regarding LLL support in the early phase:

- tasks that can be performed as group work

- problem-based tasks

- the use of individual-focused techniques in evaluation

- letting every student learn at their own pace and control their own time-management

- preparing students to make goal-oriented efforts in their learning processes

These tasks and methods are obviously more applicable in the lower grades of primary school, and are relatively difficult to transfer to kindergarten education. However, kindergarten age is also an important part of the early phase of LLL. Ránki (2002) also draws attention to the fact that children can only be effectively motivated for lifelong learning only if their teachers have positive attitudes towards learning and teaching. She also mentions the importance of parental influence.

The main functions of the early stage are covered in the guidelines published by the OECD and the European Commission and in the criteria developed in international and national framework strategies. These also form the basis of local educational regulatory documents (Hungarian Government, 2005, 2014; European Commission 2017, 2018; European Council, 2000; NAT, 2012; ONOAP, 2012; OECD, 2007, p. 4).

A Hungarian review of the Delors report (1997) identifies four main pillars in early childhood education (preschooling) around which lifelong learning is based at kindergarten age:

- socialization role

- preparing children for school

- kindergarten attendance prevents against early school leaving (chil- 
dren who receive pre-school education are much less likely to drop out of school)

- equal opportunities for learning (Majzikné, 1997)

The early stages of lifelong learning are addressed not only in education policy regulation, but in educational science as well. However, most of the relevant education research is based on the critical analysis and interpretation of the educational policy documents described earlier. Maróti (2002) lists some directions for educational development that may help children become effective lifelong learners in the future:

- developing self-directed learning

- problem-based learning

- developing cognitive skills as a basis for meaningful learning

- developing communication and cooperation in everyday life situations

- developing critical thinking

- divergent thinking

- compensation for social disadvantages (Maróti, 2002)

Additionally, Harangi (2009) highlights the importance of developing a positive attitude to learning, a positive self-image, and learner-centred teaching methods in the early phase.

In both educational policy documents and educational science theory the development of lifelong learning in preschool and lower school age groups is seen as an introductory phase. This phase of public education prepares children for learning to learn and plays an important role in the development of social competences that allow children to integrate effectively in society.

In addition to documents rooted in education policy, there are several pedagogical and psychological models in educational science that explore the individual-centred components of lifelong learning. Only those that are relevant to this research will be presented here. It is important to note, however, that most models with a psychological, sociological, or pedagogical focus are aimed at adult learning, so these models have limited application to preschool development.

Recent research trends in lifelong learning rely on other approaches as well. Kim (2016) explored the topic using a meta-analysis based on information from international databases (e.g. Eurostat). The author analysed the databases based on a theoretical model and created an index representing LLL effectiveness for each country. 
However, in educational science research questionnaire surveys are more popular. These usually use Likert-scales to measure aspects of lifelong learning: perceived LLL competences; personality characteristics typically found in effective lifelong learners; students' or teachers' work on lifelong learning or teacher's attitudes towards LLL (Crick et. al., 2004; KSH, 2004; Coşkun, Demirel, 2010; Sahin, Akbasli, Yelken, 2010; Kirby et. al., 2010; Uzunboylu, Hürsen, 2011; Lüftenegger et. al., 2012 Günüc et al., 2014; Feng, HA 2016; Hursen, 2016; Tezer, Aynaz, 2018; Selcuk et. al., 2018; Rittilin et. al., 2018).

The qualitative studies have been conducted primarily via interviews (Klug et al., 2014; Hursen, 2014) or impact assessments of developmental programs (Finsterwald et. al., 2013).

Since the basis of the present comparative study is pedagogical, the theoretical framework is created by using pedagogical models. To develop the theoretical framework of the research, we adapted two pedagogical psychological models created by Austrian research groups (Lüftenegger et. al., 2012; Finsterwald et al., 2013) (Figure 1).

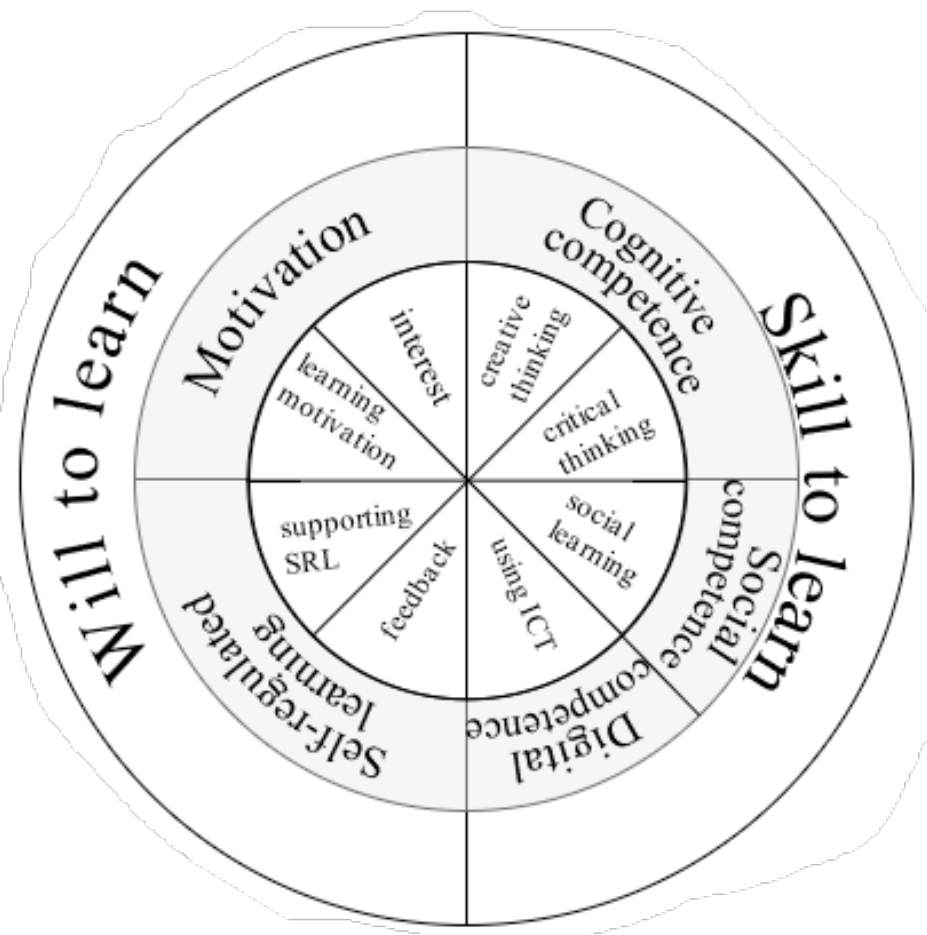

Figure 1 Main components of support for lifelong learning based on Finsterwald et al. (2013) and Lüftenegger et al. (2012) 
Lüftenegger (2012) highlights two common factors in the research on lifelong learning that can be observed in most models. These are factors influencing learning intentions (will to learn) and learning skills that are specific to the lifelong learning approach (skill to learn). Finsterwald et al. (2013) emphasize that the two most important factors are learning motivation and self-directed learning. While learning motivation receives more emphasis in the Hungarian framework strategy, self-directed learning is a prominent element of the key objectives of the German framework document. (Hungarian Government, 2014; Bund -Länder-Commission, 2004).

Based on the literature review and pedagogical and psychological models of LLL, we can see that some common pedagogical elements dominate in the basic phase of lifelong learning (Table 2).

Table 2 Pedagogical elements of the foundational phase of LLL based on the literature review

\begin{tabular}{|c|c|c|c|}
\hline \multicolumn{3}{|c|}{ Theoretical model } & Pedagogical elements of LLL* \\
\hline \multirow{4}{*}{$\begin{array}{l}\text { Will to } \\
\text { learn }\end{array}$} & \multirow[b]{2}{*}{ Motivation } & interest & positive learning attitudes \\
\hline & & learning motivation & $\begin{array}{l}\text { goal-orientated approach } \\
\text { increasing self-efficacy } \\
\text { learner-centred teaching methods }\end{array}$ \\
\hline & \multirow{2}{*}{$\begin{array}{l}\text { Self-regulated } \\
\text { learning }\end{array}$} & feedback & individual-focused evaluation \\
\hline & & supporting SRL & $\begin{array}{l}\text { planning } \\
\text { time-management }\end{array}$ \\
\hline \multirow{4}{*}{$\begin{array}{l}\text { Skill to } \\
\text { learn }\end{array}$} & \multirow[b]{2}{*}{$\begin{array}{l}\text { Cognitive } \\
\text { competence }\end{array}$} & creative thinking & \multirow{2}{*}{$\begin{array}{l}\text { problem-based learning } \\
\text { preparing for school } \\
\text { meaningful learning } \\
\text { learning in everyday-life situations } \\
\text { divergent thinking }\end{array}$} \\
\hline & & critical thinking & \\
\hline & Social competence & social learning & $\begin{array}{l}\text { group work } \\
\text { socialization } \\
\text { compensation of social } \\
\text { disadvantages } \\
\text { communication } \\
\text { cooperation }\end{array}$ \\
\hline & $\begin{array}{l}\text { Digital } \\
\text { competence }\end{array}$ & using ICT & using ICT tools \\
\hline $\begin{array}{l}{ }^{*} \text { Base } \\
\text { Haran }\end{array}$ & $\begin{array}{l}\text { the work of Delor } \\
009\end{array}$ & 1997; Majzik, 199 & Inki, 2002; Maróti, 2002; \\
\hline
\end{tabular}

Table 2 summarizes the pedagogical elements that are important and effective in the foundational phase of LLL based on the literature review. These aspects will inform the collection of LLL elements in prospective kindergarten teachers' views on learning. 
In the next section, the German and Hungarian lifelong learning concepts will be compared. In the analysis, we focus on the recommendations given in the documents for supporting LLL and compare these in the two countries. The theoretical model of this study forms the basis of the analysis (Table 2).

\section{International Comparison of Effectiveness in Lifelong Learning}

Hungary and Germany are an excellent choice for comparison not just because of their positions on the GLLI, but because of the results of Óhidy's (2012) study. Several other factors explain why the two countries' education systems went through different developmental phases. This has played an important role in improving the effectiveness of lifelong learning. Although there are relevant political, economic and social differences between the two countries, there are more important differences in the Hungarian and German education systems that need highlighting. While Germany's education system is organized by it's provinces, Hungary has a more central one (Óhidy, 2012).

Since Hungarian regulatory documents apply nationally, these very detailed national documents determine the local regulations. By contrast, in Germany each province issues its own documents. In the later analysis we review documents that are based on the Bavarian regulations for comparison, as the sample for the qualitative analysis was from a pedagogical institution in Munich.

Comparison of Hungary and Germany based on their framework strategy and GLLI

Kim (2016) conducted unique research using the method of meta-analysis in the topic of LLL. The author's method was based on previous studies (ELLI project) comparing 23 European countries using 17 indicators. The research revealed that the GLLI index did not provide in-depth assessment of LLL in each country. Kim (2016) wanted to fill this gap by proposing the GLLI.

The theoretical framework of the GLLI is formed of the four pillars outlined in the Delors report (1996) (Table 3).

In the appendix of Kim's paper, some detailed tables show the ranking of the 88 countries, where Hungary came 39th and Germany 12th. Germany therefore came in the "strong" third of the index, while Hungary was placed in the "intermediate" category in terms of LLL effectiveness (Table 4). 
Table 3 Delors' four pillars as defined in the theoretical framework of the GLLI

\begin{tabular}{|l|l|}
\hline Learning to learn & $\begin{array}{l}\text { Learning within the formal education system } \\
\text { (preschool, school, university ...) }\end{array}$ \\
\hline Learning to do & Vocational, job-related learning \\
\hline Learning to live together & Learning for social cohesion \\
\hline Learning to be & Learning as personal growth \\
\hline
\end{tabular}

Source: Kim, 2016

Table 4 Detailed results of GLLI for selected countries

\begin{tabular}{|l|c|c|c|c|c|}
\hline & \multicolumn{5}{|c|}{ Country scores (max. 7 points) } \\
\cline { 2 - 6 } & GLLI score & $\begin{array}{c}\text { Learning } \\
\text { to learn }\end{array}$ & $\begin{array}{c}\text { Learning } \\
\text { to do }\end{array}$ & $\begin{array}{c}\text { Learning } \\
\text { to live } \\
\text { together }\end{array}$ & $\begin{array}{c}\text { Learning } \\
\text { to be }\end{array}$ \\
\hline Norway (1) & 5.70 & 5.74 & 4.90 & 6.52 & 5.65 \\
\hline Australia (2) & 5.66 & 6.24 & 4.18 & 6.15 & 6.09 \\
\hline Iceland (3) & 5.64 & 5.73 & 4.58 & 6.22 & 6.06 \\
\hline Germany (12) & 5.30 & 5.36 & 4.51 & 6.11 & 5.21 \\
\hline Hungary (39) & 4.52 & 5.03 & 3.01 & 5.53 & 4.53 \\
\hline Bangladesh (79) & 3.06 & 2.22 & 3.53 & 4.18 & 2.32 \\
\hline Pakistan (80) & 2.73 & 1.78 & 3.04 & 4.00 & 2.10 \\
\hline Nigeria (81) & 2.71 & 1.37 & 3.20 & 3.81 & 2.47 \\
\hline
\end{tabular}

Source: Kim, 2016

According to that study, Hungary, in the "intermediate" third, scored lower on all four pillars than Germany did, which featured in the "strong" third of the index. According to the index, Hungary's greatest deficit is in the "learn to work" category; which is closely linked to teacher training. In light of this, it would be interesting to compare the two countries on this aspect as well.

Framework strategic objectives for lifelong learning in Hungary and Germany

Based on Óhidy's study (2012) and the documents reviewed, one can conclude that the concept of lifelong learning is basically very similar in the two countries. The two documents differ only in parts, such as the interpretation of each age stage of LLL, the specific tasks, and the focus on formal, informal and non-formal forms of learning. 
Looking specifically at the objectives of the current framework strategy documents, there are only minor differences. Regarding preschool education, Hungary's framework strategy document notes that preschooling plays a key role in successful LLL, but highlights only one aspect of the implementation plans: "Although positive efforts have been made to develop tolerance and non-prejudice in pre-school education, public education and teacher training, $[\ldots]$ their effectiveness is not yet visible in practice." (Hungarian Government, 2014, p. 77).

As the next step in the foundational phase of lifelong learning, the document emphasizes the importance of teaching basic knowledge and developing skills and competences in the lower grades of primary school. However, readers are given no details on how effective the government has been in achieving these goals nor about the specific tasks related to these aims.

It is problematic that in the Hungarian school system, in the first four years of primary school basic skills are not developed and deepened with sufficient attention and thoroughness. (Hungarian Government, 2014, p. 78.)

The quotes and details given above show that although Hungary has regulatory documents on the development of LLL, no measures have been taken to implement them and there is no feedback system for monitoring and improving efficiency.

In Germany, however, each province approaches the practical implementation differently, but based on the EU framework strategy (Bund-LänderKomission, 2004).

The following table summarizes the main objectives of the Hungarian and German framework strategy papers on lifelong learning (Table 5). The goals are similar and are categorized accordingly in the two column in the table.

The two goal systems share common elements that are universal goals in support for lifelong learning:

- supporting informal learning beyond the formal school system,

- developing the basic skills and competences needed for lifelong learning,

- personalized learning/learner support and development,

- promoting learning by establishing a culture of learning,

- and providing learning opportunities for all children and adults. 
Table 5 Main objectives of Hungary's (2014) and Germany's (2004) framework strategy for lifelong learning

\begin{tabular}{|l|l|}
\hline $\begin{array}{l}\text { Main goals of Hungary's framework strat- } \\
\text { egy for LLL }\end{array}$ & $\begin{array}{l}\text { Main goals of Germany's framework } \\
\text { strategy for LLL }\end{array}$ \\
\hline $\begin{array}{l}\text { learning throughout life (,learning does not } \\
\text { end upon leaving the formal school system") } \\
\text { (The Government of Hungary, 2014; 9. o.) }\end{array}$ & $\begin{array}{l}\text { acceptance and support for informal } \\
\text { learning }\end{array}$ \\
\hline $\begin{array}{l}\text { age-appropriate development of skills and } \\
\text { competencies }\end{array}$ & self-directed learning \\
\hline \begin{tabular}{l} 
development of skills and competencies \\
\hline needs of the learner
\end{tabular} & networking \\
\hline $\begin{array}{l}\text { promoting a new learning and innovative } \\
\text { pedagogical culture }\end{array}$ & modulation \\
\hline $\begin{array}{l}\text { eliciting learning motivation, providing } \\
\text { a second chance }\end{array}$ & learning support \\
\hline $\begin{array}{l}\text { providing learning opportunities in } \\
\text { response to new learning needs }\end{array}$ & \\
\hline
\end{tabular}

At the same time, there are differing objectives as well. The German strategy emphasizes the need for networking. Kindergartens and primary schools, and primary and secondary schools should work closely together, building on the work of the other and communicating regularly in networks. In addition, the German strategy includes goals of promoting self-directed learning and modulating learning and teaching content. This last goal is aimed at "young adults" and represents a realistic aim in the approach to lifelong learning. The Hungarian document states that learning opportunities must be expanded to meet any new needs that arise so that everyone can immediately acquire the new skills, competencies and knowledge they need.

Óhidy's $(2012,2014)$ comparison of Hungary and Germany goes beyond a simple analysis of education policy regulation. The author compared how Hungarian and German scientific papers interpret and implement LLL on the field of education. The author reveals that there is a similar number of articles that deal in some way with the concept of lifelong learning $\left(\mathrm{N}_{\mathrm{G}}=24\right.$; $\mathrm{N}_{\mathrm{H}}=25$ ). In addition both countries consider the paradigm to be an essential part of education policy and practice. The papers use approximately the same interpretive framework in their definitions. However, the nature of the research conducted on lifelong learning differs in the two countries. While 
the Hungarian research consists mostly of a content analysis of education policy documents, the German authors tend to publish more empirical studies.

The reasons for the differences are to be found in education policy attitudes in the two countries, in the development of education policy, and the structure of their education systems (Óhidy, 2014).

Comparison of training and output requirements in Hungary and Germany in approaches to lifelong learning

In this section, the training and output requirements of the teacher training institutions attended by the students participating in the research will be compared. The comparison is based on the research questions formulated in the introduction and relating to elements of LLL (Q1), and differences between the two countries' documents (Q2).

Before we can interpret the training and output requirements of the two teacher training institutions, it is important to clarify some of the main differences in public education in Germany and Hungary. In Hungary preschool education is compulsory from the age of three. In Germany (as in many other EU countries) it is not and compulsory schooling begins at the age of six, typically at primary school (Eckhardt, 2017). However, before entering primary school, children can attend educational and care facilities: a "Schulkindergarten" or "Vorschule" which focus specifically on preparing children for school, or a "Kindergarten" which is much more similar structurally to a Hungarian kindergarten (Eckhardt, 2017).

We also need to point out that in Germany teacher training and qualifications are not uniform and so may differ from province to province, including pre-school education. Furthermore, primary-school teacher and kindergarten teacher training in Germany are taught at different levels, making it even more difficult to compare German and Hungarian prospective kindergarten teachers. In Hungary, kindergarten student teachers can study at the same (university-)level training, and in most cases at the same higher education institution as primary school student teachers do, while in Germany kindergarten teachers are being trained separately (Eckhardt, 2017).

Given these differences, there is no point comparing national documents. Instead we will focus on the specific training and output requirements of the two teacher training institution. On further analysis it transpires that there 
is a large number of documents and so we limit our analysis to the regulations that are relevant to the research questions $(\mathrm{Q} 1, \mathrm{Q} 2)$. Therefore, we do not undertake an in-depth analysis of these regulations, but collect information relevant to the research questions $(\mathrm{Q} 1, \mathrm{Q} 2)$. This is an important step in finding out whether the pedagogical institution's approach to learning in general and LLL in particular are reflected in the views of prospective kindergarten teachers. To ensure anonymity, the two documents used in this paper are labelled TOR $_{\mathrm{G}}$ (German institution's Training and Output Requirements) and $\mathrm{TOR}_{\mathrm{H}}$ (Hungarian institution's Training and Output Requirements).

The first striking difference between the two documents is the size. While the German training requirements are described in 8 pages, the Hungarian ones take up 19 pages $\left(\mathrm{TOR}_{\mathrm{G}}\right.$ 2019; $\left.\mathrm{TOR}_{\mathrm{H}}, 2017\right)$. The main elements of the Hungarian document are very similar to those in the national regulations, which share many common elements with the Training and Output Requirements for kindergarten teachers in Hungary (KKK, 2016).

The training and output requirements of the two selected institutions contain the same basic elements and interpretive framework. They set out the training content, timeframe and a more detailed description, the nature of the exams and possible forms of evaluation, as well as the knowledge content elements divided into modules or sub-units. In the next part of the study, the required knowledge and ability content will be compared from the aspect of lifelong learning.

The German training and output requirements include a short paragraph on the main goal of the training, which is the professional development of students based on academic foundations (theory) and practice. In contrast, the Hungarian teacher training institution builds on the national document, which emphasizes the practical implementation rather than the theoretical foundations and highlights the importance of the ability to perform the tasks of a kindergarten teacher (KKK, 2016; TOR $_{\mathrm{H}}$, 2017). Nagy (2003) highlights the need for knowledge sharing in knowledge-based societies. This is also closely connected to the LLL framework.

The objectives of the German approach fit in with the framework strategy for lifelong learning. The strategy fulfils the networking criterion and links the theory and science with the practice. The importance of communicating with parents is also one of the output requirements, and is emphasized by Ránki (2002) in her study $\left(\mathrm{TOR}_{\mathrm{G}}\right.$, 2019). 
The Hungarian training and output requirements are significantly more detailed than the German ones. Besides the required knowledge and competencies, prospective kindergarten teachers have to be capable of comprehensively developing the child's personality, and of building on the children's individual characteristics, facilitating their learning and reflecting on their own professional work and the children's development. In addition, similarly to the German requirements, under the Hungarian training and output requirements, prospective kindergarten teachers have to maintain an active relationship with partner institutions (nursery school, primary school) and they have to be familiar with the work of these institutions and build on their results $\left(\mathrm{TOR}_{\mathrm{H}}, 2017\right.$; $\left.\mathrm{TOR}_{\mathrm{G}}, 2019\right)$.

Although, it would be interesting to conduct a deeper analysis of these documents, that was not the purpose of this research. After reviewing the documents, we could see that the content of the two documents overlapped with the framework strategies and that there were minor differences in the output requirements of the two countries: the German document emphasizes the theory behind networking and the Hungarian document was more practice-oriented in approach. On the other hand, while the Hungarian document seems rather prescriptive, the requirements of the German one tend to be given as recommendations.

\section{Sample and Methods of the Qualitative Study}

During the data collection, the German $\left(\mathrm{N}_{\mathrm{G}}=14\right)$ and Hungarian $\left(\mathrm{N}_{\mathrm{H}}=\right.$ 14) kindergarten student teachers were asked to give associations related to kindergarten and school learning. The upper limit was three words, and no lower limit was given. In both cases, the data collection took place during university seminars. Once they had written down the associations, we held a group discussion to categorize them by answering the following questions: "What do you think about the words you wrote? Can they be connected to typically formal, informal or nonformal learning processes?" This phase of the activity was not part of the study, but one interesting finding was that the German kindergarten student teachers identified the school learning concepts as formal learning and related the kindergarten learning terms more to informal and non-formal categories. The situation was a little more nuanced in the case of the Hungarian subsample. The data collection of the German subsample took place in the chosen teacher training institution in Munich, in December 2019 and the Hungarian subsample data was collected in February 2020 in Budapest, Hungary. The kindergarten student teachers selected for the research were in their final year (third year stu- 
dents), so it could be assumed that their views represent the institution's LLL approach (see the previous section: Comparison of training and output requirements in Hungary and Germany in approaches to lifelong learning). The gender ratio of the sample reflected the national proportions in both the German and Hungarian samples, which means that all the participating students were female.

The respondents' associations were collated in an Excel spreadsheet and labelled as follows: country, word-kindergarten 1, word-kindergarten 2, word-kindergarten 3, word-school 1, word-school 2, word-school 3. Once the data had been recorded and translated, the necessary calculations could be performed to create the Verges' association matrices.

During the analysis, the data were interpreted by creating Vergés' association matrices for each subsample. The results were interpreted separately for kindergarten and school learning and these two learning phases were compared (Vergés, 1994 In Sándor, 2009).

In the analysis of the matrices, according to the two research questions, the results are examined from two main perspectives: (Q3) Can the lifelong learning approach be identified in the prospective kindergarten teachers' views on learning? (Q4) How does the interpretation of LLL differ between the two countries based on the prospective kindergarten teachers' views on learning? (Table 1)

$\begin{aligned} & \text { Content } \\ & \text { ranking } \\ & \text { mostly in first } \\ & \text { or second } \\ & \text { place }\end{aligned}$
$\begin{aligned} & \text { Content } \\ & \text { ranking } \\ & \text { mostly } \\ & \text { second or } \\ & \text { third place }\end{aligned}$
$\begin{aligned} & \text { Item variety } \\ & \text { Low rank } \\ & (<2.25)\end{aligned}$

Figure 2. Explanation of Vergés' association matrix based on Sándor Source: Sándor, 2009 
The association matrices contain the following information (Vergés, 1994 In: Sándor, 2009) (Figure 2):

- Associations are given in separate columns for preschool and primary school learning. Two values were awarded to each word in brackets: association (average rank; relative frequency)

- Average rank indicates the average position (1st, 2nd or 3rd) of the given association in the order of mentions. The number is therefore always between 1 and 3 , as students could mention a term in up to three places in total.

- Diversity: This number indicates the number of different associations. It ranges from 0 to 1 and is obtained by dividing the number of different answers by the total number of answers.

- Rarity index: This number ranges from 0 to 1 and is obtained by dividing the number of the words occurring once by the number of the words occurring more than once.

In the next section we present the results and discuss the LLL elements in the associations. After that we analyse the matrices and compare the Hungarian and German subsamples.

\section{Interpretation of the Results Based on the Theoretical Models and Framework Strategies}

The results are illustrated in three tables: Tables 6 and 7 answer Q3 and list the terms relating to lifelong learning in the associations. Tables 8 and Table 9 show all the associations given by the Hungarian (Table 8) and German (Table 9) subsamples in the Vergés' matrices.

Among the Hungarian kindergarten teacher students' associations, we found a total of 11 words relating to kindergarten that can be linked to lifelong learning, and only six that link primary school learning to lifelong learning (Table 6). There is a large overlap between the LLL terms relating to school and kindergarten learning. However, the kindergarten related terms tend to come under the "motivation to learn and arouse interest" categories, whereas the school-related associations also appear under "learning to learn", which is linked to self-directed learning.

Looking at the results for the German subsample, we can see that the picture is much more diverse. Participants mentioned a total of 14 terms in relation to LLL and kindergarten and seven related to school education. Proportion-wise, it is striking that the German subsample contains more LLL terms related to the social dimension (5 associations) (Table 7). 
Table 6 Lifelong learning associations in the Hungarian subsample responses

\begin{tabular}{|c|c|c|c|c|c|}
\hline & & & Pedagogical & $\begin{array}{l}\text { LLL el } \\
\text { in the } r\end{array}$ & $\begin{array}{l}\text { ments } \\
\text { sponses }\end{array}$ \\
\hline & Theoretical $n$ & odel & $\begin{array}{l}\text { elements } \\
\text { of } L L L^{*}\end{array}$ & kindergarten & primary \\
\hline & & & & F (\%) & F (\%) \\
\hline & & & $\begin{array}{l}\text { positive } \\
\text { learning } \\
\text { attitudes }\end{array}$ & $\begin{array}{l}\text { playful (28.6) } \\
\text { joy (14.3) } \\
\text { interesting }\end{array}$ & $\begin{array}{l}\text { interesting } \\
(\mathbf{2 . 4 )} \\
\text { inspiring (2.4) }\end{array}$ \\
\hline $\begin{array}{l}\text { Will to } \\
\text { learn }\end{array}$ & Motivation & $\begin{array}{l}\text { interest } \\
\text { and } \\
\text { learning } \\
\text { motivation }\end{array}$ & $\begin{array}{l}\text { goal-orientat- } \\
\text { ed approach } \\
\text { increasing } \\
\text { self-efficacy } \\
\text { learner- } \\
\text { centred } \\
\text { teaching } \\
\text { methods }\end{array}$ & $\begin{array}{l}(2.4) \\
\text { free }(7.1)\end{array}$ & \\
\hline & & feedback & $\begin{array}{l}\text { individual- } \\
\text { focused } \\
\text { evaluation }\end{array}$ & & \\
\hline & learning & $\begin{array}{l}\text { supporting } \\
\text { SRL }\end{array}$ & $\begin{array}{l}\text { planning } \\
\text { time-manage- } \\
\text { ment }\end{array}$ & $\begin{array}{l}\text { constant } \\
(4.8)\end{array}$ & $\begin{array}{l}\text { constant } \\
\mathbf{( 2 . 4 )} \\
\text { learning to } \\
\text { learn (2.4) }\end{array}$ \\
\hline & $\begin{array}{l}\text { Cognitive } \\
\text { competence }\end{array}$ & $\begin{array}{l}\text { creative } \\
\text { thinking }\end{array}$ & $\begin{array}{l}\text { problem- } \\
\text { based learn- } \\
\text { ing } \\
\text { preparing for } \\
\text { school } \\
\text { meaningful } \\
\text { learning }\end{array}$ & $\begin{array}{l}\text { experience } \\
\mathbf{( 1 4 . 3 )} \\
\text { spontaneous } \\
(7.1) \\
\text { creative }(4.8) \\
\text { discovering } \\
(\mathbf{4 . 8 )}\end{array}$ & $\begin{array}{l}\text { experience } \\
\text { (7.1) } \\
\text { practice (2.4) }\end{array}$ \\
\hline $\begin{array}{l}\text { Skill to } \\
\text { learn }\end{array}$ & & $\begin{array}{l}\text { critical } \\
\text { thinking }\end{array}$ & $\begin{array}{l}\text { learning in } \\
\text { everyday-life } \\
\text { situations } \\
\text { divergent } \\
\text { thinking }\end{array}$ & $\begin{array}{l}\text { constructive } \\
(2.4)\end{array}$ & \\
\hline & $\begin{array}{l}\text { Social } \\
\text { competence }\end{array}$ & social learning & $\begin{array}{l}\text { group work } \\
\text { socialization } \\
\text { compensation } \\
\text { of social } \\
\text { disadvantages } \\
\text { communica- } \\
\text { tion } \\
\text { cooperation }\end{array}$ & $\begin{array}{l}\text { teamwork } \\
(2.4)\end{array}$ & \\
\hline & $\begin{array}{l}\text { Digital } \\
\text { competence }\end{array}$ & using ICT & $\begin{array}{l}\text { using ICT } \\
\text { tools }\end{array}$ & & \\
\hline
\end{tabular}


Table 7 Lifelong learning associations in the German subsample responses

\begin{tabular}{|c|c|c|c|c|c|}
\hline & & & Pedagogical & $\begin{array}{r}\text { LLL el } \\
\text { in the } r\end{array}$ & $\begin{array}{l}\text { ments } \\
\text { sponses }\end{array}$ \\
\hline & Theoretical 1 & odel & $\begin{array}{l}\text { elements of } \\
\text { LLL* }\end{array}$ & kindergarten & primary \\
\hline & & & & F (\%) & F (\%) \\
\hline & & & $\begin{array}{l}\text { positive } \\
\text { learning } \\
\text { attitudes }\end{array}$ & $\begin{array}{l}\text { playful (15.4) } \\
\text { free (2.6) } \\
\text { joy }(7.7)\end{array}$ & playful (2.4) \\
\hline $\begin{array}{l}\text { Will to } \\
\text { learn }\end{array}$ & Motivation & $\begin{array}{l}\text { interest } \\
\text { and } \\
\text { learning } \\
\text { motivation }\end{array}$ & $\begin{array}{l}\text { goal-orientat- } \\
\text { ed approach } \\
\text { increasing } \\
\text { self-efficacy } \\
\text { learner- } \\
\text { centred } \\
\text { teaching } \\
\text { methods }\end{array}$ & & \\
\hline & & feedback & $\begin{array}{l}\text { individual- } \\
\text { focused } \\
\text { evaluation }\end{array}$ & $\begin{array}{l}\text { individual } \\
(2.6)\end{array}$ & \\
\hline & learning & $\begin{array}{l}\text { supporting } \\
\text { SRL }\end{array}$ & $\begin{array}{l}\text { planning } \\
\text { time-manage- } \\
\text { ment }\end{array}$ & $\begin{array}{l}\text { self-sufficien- } \\
\text { cy (2.6) } \\
\text { learning envi- } \\
\text { ronment (2.6) }\end{array}$ & $\begin{array}{l}\text { self-sufficien- } \\
\text { cy }(2.4)\end{array}$ \\
\hline & $\begin{array}{l}\text { Cognitive } \\
\text { competence }\end{array}$ & $\begin{array}{l}\text { creative } \\
\text { thinking }\end{array}$ & $\begin{array}{l}\text { problem- } \\
\text { based learning } \\
\text { preparing for } \\
\text { school } \\
\text { meaningful } \\
\text { learning } \\
\text { learning in }\end{array}$ & $\begin{array}{l}\frac{\text { spontaneous }}{(2.6)} \\
\text { physical } \\
\text { activities }(7.7) \\
\text { cognitive }(2.6)\end{array}$ & $\begin{array}{l}\text { learning } \\
\text { activities (4.8) } \\
\text { competencies } \\
(2.4) \\
\text { active (2.4) }\end{array}$ \\
\hline & & $\begin{array}{l}\text { critical think- } \\
\text { ing }\end{array}$ & $\begin{array}{l}\text { situations } \\
\text { divergent } \\
\text { thinking }\end{array}$ & & \\
\hline $\begin{array}{l}\text { Skill to } \\
\text { learn }\end{array}$ & $\begin{array}{l}\text { Social } \\
\text { competence }\end{array}$ & social learning & $\begin{array}{l}\text { group work } \\
\text { socialization } \\
\text { compensation } \\
\text { of social } \\
\text { disadvantages } \\
\text { communica- } \\
\text { tion } \\
\text { cooperation }\end{array}$ & $\begin{array}{l}\text { social compe- } \\
\text { tences (15.4) } \\
\text { conversations } \\
(5.1) \\
\text { presence of } \\
\text { the pedagogue } \\
(2.6) \\
\text { sharing (2.6) } \\
\text { teamwork } \\
\underline{\mathbf{2 . 6}}\end{array}$ & $\begin{array}{l}\text { competencies } \\
(2.4) \\
\text { teamwork } \\
\mathbf{( 2 . 4 )}\end{array}$ \\
\hline & $\begin{array}{l}\text { Digital } \\
\text { competence }\end{array}$ & using ICT & $\begin{array}{l}\text { using ICT } \\
\text { tools }\end{array}$ & & \\
\hline
\end{tabular}


Comparing the results of the German subsample with the Hungarian ones, we can see that in both cases the participants mentioned - almost or exactly - twice as many LLL terms in connection with kindergarten education as they did with primary school education (Table 6, 7). However, it is interesting that of the dimensions in the theoretical model, ICT competence was not mentioned at all, and there was only one association relating to feedback (Figure 1). Overall, we can see that in terms of the two main dimensions (Figure 1), the Hungarian subsample participants named LLL elements in approximately equal proportions in the "will to learn" ( 8 different associations) and "skill to learn“ (7 different associations) dimensions. In the German subsample there were six terms in the "will to learn" dimension and 11 in the "skill to learn" dimension. Thus, the German subsample thought there was a greater need for learning-skill acquisition and the Hungarian subsample focused on both learning motivation and the competences necessary for lifelong learning.

The following tables show the results of the Vergés" matrices of the associations given by the Hungarian (Table 8) and German subsample (Table 9). The keywords appearing for both learning levels (kindergarten and primary school) within a single subsample (i.e. either the Hungarian or German subsample) are given in bold. Terms that can be found in both the Hungarian and German subsamples are underlined. And terms that meet both criteria are underlined and emboldened (i.e. these are terms that can be found in both the Hungarian and German subsamples and are mentioned in relation to kindergarten learning and primary school learning at the same time).

He terms "playfulness", "basic" and "group work" meet the last criterion. This means that both Hungarian and German kindergarten student teachers think that playful learning activities ("playfulness") and cooperative tasks are social activities ("groupwork") that are important in kindergarten and primary school learning and that these phases are also key to the individual's life ("basic")

In line with international recommendations on the basic phase of lifelong learning (i.e. pre-school and lower primary school), prospective kindergarten teachers also thought that playful (thus motivating) learning activities during this period play a key role in individuals' lives by providing them with a good basis for future schooling as well as for later independent life. The term group work, and synonyms thereof, can also relate to the development of social competencies based on international regulatory documents and psychological models (Tables 8 and 9). 
Moreover, there are some elements that appeared in both the Hungarian and German subsamples, but that ultimately proved to be specific to age or education level. Hungarian and German participants believed that learning occurs "spontaneously" at kindergarten age. This association often occurred together with playfulness as an important feature of kindergarten learning. However, there was a more extensive range of similar associations related to primary-school learning, which could lead us to conclude that prospective kindergarten teachers think similarly about preschool education and that their views are more diverse about school learning (Germany: $D_{\text {kindergar- }}$ ten $=0.33 ; \mathrm{D}_{\text {school }}=0.69$; Hungary: $\left.\mathrm{D}_{\text {kindergarten }}=0.56 ; \mathrm{D}_{\text {school }}=0.62\right)$,.

Both the German and Hungarian students mentioned several stereotypical and often negative words related to primary school learning, but such utterances did not occur in connection with kindergarten. These include "knowledge (based)", "directed", "rules", "compulsion", "exhausting”, "disciplined", "counting", "reading", and "tests". It is interesting, however, that in many cases these were often the same student using pairs of opposites, such as: kindergarten: free ßà school: compulsory; kindergarten: spontaneous ßàschool: directed.

Reviewing the answers of the two subsamples, it can be observed that while in the German subsample the answers relating to kindergarten learning are much more divergent $\left(D_{\text {kindergarten }}=0.33 ; D_{\text {school }}=0.69\right)$, in the Hungarian subsample this difference is much less conspicuous $\left(D_{\text {kindergarten }}=0.56\right.$; $\mathrm{D}_{\text {school }}=0.62$ ). The reason probably lies in the nature of higher education in the two countries (Eckhardt, 2017; Óhidy, 2014). In the Hungarian higher education system, kindergarten teachers and primary school teachers often receive their training together, not just in the same building, but often in the same classes (and later their career pathway is subject to similar criteria and requirements as well). In Germany, primary school teachers are trained separately from kindergarten teachers, at university level.

Therefore, one might assume that the Hungarian subsample's views of these elements of primary school learning would be similar to their views of kindergarten, but the difference is not as obvious as one might expect.

Reviewing the results of the Hungarian subsample, we can see that the kindergarten student teachers paid significantly less attention to learning motivation in relation to both kindergarten and school learning than expected. Among the Hungarian associations, the terms playful $(1.6 ; 28.6 \%)$, free $(2.33 ; 7.1 \%)$ "interesting" $(1 ; 2.4 \%)$, “joy" $(2.5 ; 14.3 \%)$ and "inspiring” (2; 
Table 8 Hungarian subsample associations relating to kindergarten and primary school learning

\begin{tabular}{|c|c|c|c|c|c|}
\hline \multicolumn{3}{|c|}{ Learning in kindergarten } & \multicolumn{3}{|c|}{ Learning in primary school } \\
\hline & $\begin{array}{c}\text { High } \\
\text { frequency } \\
\text { (min. 10\%) }\end{array}$ & $\begin{array}{c}\text { Low frequen- } \\
\text { cy }\urcorner^{*} \\
(>10 \%)\end{array}$ & $\begin{array}{c}\text { High } \\
\text { frequency } \\
\text { (min. 10\%) }\end{array}$ & $\begin{array}{r}\text { Low fre } \\
\quad>\end{array}$ & $\begin{array}{l}\text { uency }{ }^{*} \\
\text { \%) }\end{array}$ \\
\hline 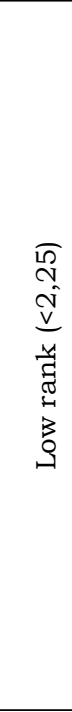 & $\begin{array}{l}\text { playful } \\
(1.6 ; 28.6 \%) \\
\text { experience } \\
(2.16 ; 14.3 \%)\end{array}$ & $\begin{array}{l}\frac{\text { spontaneous }}{(2 ; 7.1 \%)} \\
\text { creative } \\
(2 ; 4.8 \%) \\
\text { discovering } \\
\mathbf{( 2 ;} \mathbf{4 , 8 \% )} \\
\text { development } \\
(1 ; 2.4 \%) \\
\text { constructive } \\
(1 ; 2.4 \%) \\
\text { interesting } \\
\mathbf{( 1 ; 2 . 4 \% )} \\
\text { teamwork } \\
(\mathbf{1 ;} \mathbf{2 . 4 \% )}\end{array}$ & & $\begin{array}{l}\text { experience } \\
\mathbf{( 1 . 6 6 ; 7 . 1 \% )} \\
\text { frontal } \\
(1.66 ; 7.1 \%) \\
\text { constant } \\
\mathbf{( 1 ; 2 . 4 \% )} \\
\text { interesting } \\
\mathbf{( 1 ; 2 . 4 \% )} \\
\text { books } \\
(2 ; 2.4 \%) \\
\text { knowledge } \\
1,5 ; 9.5 \%) \\
\text { practice } \\
(2 ; 2.4 \%) \\
\text { reading } \\
(1 ; 2.4 \%)\end{array}$ & $\begin{array}{l}\frac{\text { directed }}{(1 ; 2.4 \%)} \\
\text { bounded } \\
(2 ; 7.1 \%) \\
\text { didactic } \\
(1 ; 4.8 \%) \\
\text { inspiring } \\
(2 ; 2.4 \%) \\
\text { compulsion } \\
\underline{(1 ; 2.4 \%)} \\
\text { boring } \\
(2 ; 2.4 \%) \\
\text { exhausting } \\
\frac{(1 ; 2.4 \%)}{\text { intensive }} \\
\frac{(2 ; 2.4 \%)}{\text { discipline }} \\
\underline{(3 ; 2.4 \%)} \\
\frac{\text { counting }}{(2 ; 2.4 \%)} \\
\end{array}$ \\
\hline 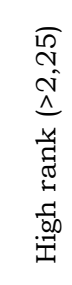 & $\begin{array}{l}\text { joy } \\
(2.5 ; 14.3 \%)\end{array}$ & $\begin{array}{l}\text { basic } \\
(3 ; 2.4 \%) \\
\text { constant } \\
(2.5 ; 4.8 \%) \\
\text { free } \\
(2.33 ; 7.1 \%) \\
\text { necessary } \\
(3 ; 2.4 \%)\end{array}$ & & $\begin{array}{l}\text { playful } \\
\mathbf{( 3 ; 2 . 4 \% )} \\
\text { discovering } \\
\mathbf{( 2 . 5 ; 4 . 8 \% )} \\
\text { novelty } \\
(3 ; 4.8 \%) \\
\text { rules }(3 ; 2.4 \%) \\
\text { tests }(3 ; 2.4 \%)\end{array}$ & $\begin{array}{l}\text { performance } \\
(3 ; 2.4 \%) \\
\text { learning to } \\
\text { learn }(3 ; 2.4 \%) \\
\text { too much } \\
(3 ; 4.8 \%) \\
\text { crucial } \\
(3 ; 2.4 \%)\end{array}$ \\
\hline $\mathrm{D}$ & \multicolumn{2}{|l|}{0.33} & \multicolumn{3}{|l|}{0.69} \\
\hline $\mathrm{Ri}$ & \multicolumn{2}{|l|}{0.43} & \multicolumn{3}{|l|}{1} \\
\hline Note & \multicolumn{5}{|c|}{$\begin{array}{l}\text { * Percentages show the relative frequency }(\%) \text { of occurrences of the word in the } \\
\text { Hungarian subsample }(\mathrm{F}=42) \\
\mathrm{D}=\text { diversity } \\
\mathrm{Ri}=\text { rarity index }\end{array}$} \\
\hline
\end{tabular}

$2.4 \%)$ can be related to motivation. This is consistent with the results of the review of the strategic framework documents and pedagogical psychological models mentioned earlier in the paper (Figure 1). The proportions in our comparison are small, but the numbers are still higher than the results for the German subsample. Related to the concept of motivation, German kindergarten student teachers mentioned only the terms "joy" (3; 7.7\%), "playful" $(1 ; 15.4 \%)$, and "free" $(2 ; 2.6 \%)$ and these ranked higher and had lower relative frequency than in the Hungarian student sample. In the Hungarian subsample, $52.4 \%$ of all the words could be related to the learning motiva- 
tion dimension in kindergarten learning and only $4.8 \%$ of the associations in the learning motivation dimension in school learning. The values for the German subsample are almost half the Hungarian ones. Of these, 25.7\% of the associations were related to 'learning motivation' in the topic of learning in kindergarten, and even less, 2.4\%, for school learning (Table 8 and 9).

Table 9 German subsample associations relating to kindergarten and primary school learning

\begin{tabular}{|c|c|c|c|c|}
\hline \multicolumn{3}{|c|}{ Learning in kindergarten } & \multicolumn{2}{|c|}{ Learning in primary school } \\
\hline & $\begin{array}{l}\text { High frequency } \\
\text { (min. 10\%) }\end{array}$ & $\begin{array}{c}\text { Low frequency* } \\
(>10 \%)\end{array}$ & $\begin{array}{l}\text { High frequency } \\
\text { (min. 10\%) }\end{array}$ & $\begin{array}{c}\text { Low frequency* } \\
(>10 \%)\end{array}$ \\
\hline 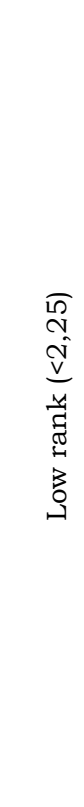 & $\begin{array}{l}\text { playful }(1 ; \mathbf{1 5 . 4 \% )} \\
\text { social } \\
\text { competences } \\
(2.16 ; 15.4 \%)\end{array}$ & $\begin{array}{l}\frac{\text { spontaneous }}{(2 ; 2.6 \%)} \\
\frac{\text { basic (2; 2.6\%) }}{\text { free }(2 ; 2.6 \%)} \\
\text { nutritional habits } \\
(1 ; 2.6 \%) \\
\text { conversations } \\
(2 ; 5.1 \%) \\
\text { presence of the } \\
\text { pedagogue } \\
(2 ; 2.6 \%) \\
\text { behaviour } \\
(1 ; 2.6 \%) \\
\text { sharing }(2 ; 2.6 \%) \\
\text { singing }(2 ; 5.1 \%) \\
\text { unconscious } \\
(1 ; 2.6 \%) \\
\text { self-sufficiency } \\
\mathbf{( 1 ; 2 . 6 \% )} \\
\text { emotional }(1 ; 2.6 \%)\end{array}$ & $\begin{array}{l}\text { rules }(1.75 ; 10 \%) \\
\text { reading } \\
\frac{(2.25 ; 10 \%)}{\text { writing }} \\
(2.5 ; 14.3 \%)\end{array}$ & $\begin{array}{l}\frac{\text { knowledge }}{(1 ; 2.4 \%)} \\
\underline{\text { counting }(2 ; 4.8 \%)} \\
\frac{\text { tests }(2 ; 2.4 \%)}{\text { compulsion }} \\
\frac{(1 ; 2.4 \%)}{\text { exhausting }} \\
\underline{(2 ; 2.4 \%)} \\
\text { intensive }(2 ; 2.4 \%) \\
\text { study trips } \\
(1 ; 2.4 \%) \\
\text { subjects }(2 ; 4.8 \%) \\
\text { thematic }(1 ; 4.8 \%) \\
\text { learning activities } \\
(1 ; 4.8 \%) \\
\text { structured } \\
(1 ; 2.4 \%) \\
\text { competencies } \\
(1 ; 2.4 \%) \\
\text { playful }(1 ; 2.4 \%) \\
\text { basic (1; 2.4\%) } \\
\text { teamwork (2; } \\
\underline{\mathbf{2 . 4 \% )}}\end{array}$ \\
\hline 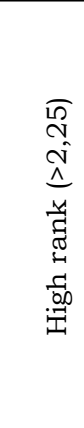 & & $\begin{array}{l}\text { joy }(3 ; 7.7 \%) \\
\text { teamwork } \\
\mathbf{3 ;} \mathbf{2 . 6 \% )} \\
\text { physical activities } \\
(2.33 ; 7.7 \%) \\
\text { individual } \\
(3 ; 2.6 \%) \\
\text { cognitive }(3 ; 2.6 \%) \\
\text { hygiene }(3 ; 2.6 \%) \\
\text { learning } \\
\text { environment } \\
(3 ; 2.6 \%)\end{array}$ & & $\begin{array}{l}\frac{\text { directed }(3 ; 2.4 \%)}{\text { disciplined }} \\
\frac{(3 ; 2.4 \%)}{\text { grades }(3 ; 2.4 \%)} \\
\text { singing }(2.5 ; 4.8 \%) \\
\text { active }(3 ; 2.4 \%) \\
\text { friendships } \\
(3 ; 2.4 \%) \\
\text { separated } \\
(3 ; 2.4 \%) \\
\text { self-sufficiency } \\
(\mathbf{3}, \mathbf{2 . 4 \% )}\end{array}$ \\
\hline $\mathrm{D}$ & \multicolumn{2}{|l|}{0.56} & \multicolumn{2}{|l|}{0.62} \\
\hline $\mathrm{Ri}$ & \multicolumn{2}{|l|}{0.38} & \multicolumn{2}{|l|}{0.43} \\
\hline Note & \multicolumn{4}{|c|}{$\begin{array}{l}\text { * Percentages show the relative frequency }(\%) \text { of the word occurrence in the Ger- } \\
\text { man subsample }(F=42) \\
D=\text { diversity } \\
\mathrm{Ri}=\text { rarity index }\end{array}$} \\
\hline
\end{tabular}


Based on international regulatory documents and the reviewed literature, it could be assumed that the participants in the German subsample would emphasize the importance of self-directed learning to a greater extent than the Hungarian students, since this important element of lifelong learning features more in German documents (Bund-Länder-Kommission, 2004 ). Nevertheless, we can conclude from the few associations that the students consider self-directed learning as an important developmental goal in kindergarten or primary school learning. The relevant terms in the German participants' associations are "individual" learning (3; $2.6 \%)$ in preschool learning and "separate" $(3 ; 2.4 \%)$ learning in primary school. At the same time, the Hungarian subsample highlighted the importance of "constructive" $(1 ; 2.4 \%)$ learning in kindergarten, "discovery" learning in both kindergarten $(2 ; 4.8 \%)$ and primary school $(2.5 ; 4.8 \%)$, and "learning to learn" $(3 ; 2.4 \%)$ in primary school education. The results for the "skill to learn" dimension show that this featured more prominently in the German subsample. Whereas $35.8 \%$ of the associations made by the Hungarian kindergarten student teachers were related to to learning-skill acquisition at kindergarten, the percentage for the German subsample was higher at $41.2 \%$. In relation to school learning, however, the proportion of learning-related abilities in the associations was relatively low in both subsamples: $9.5 \%$ in the Hungarian subsample and $12 \%$ in the German subsample. From this, we can conclude that insofar as the lifelong learning approach is concerned, views on teaching children to be good learners were stronger among the German participants.

In addition to learning motivation and self-directed learning, the development of social competencies and social relations plays a key role in both educational policy documents and pedagogical psychological models. Looking at the two tables, we can clearly see that the subsample of German kindergarten student teachers is over-represented in these associations (Table 7, Table 8). While the Hungarian respondents mentioned the term "group work" $(1 ; 2.4 \%)$ with low frequency in this category, the German participants think that the development of "social competence" $(2.16 ; 15.4 \%)$ is one of the main functions of kindergarten learning. At the same time, "group work" appears with a lower average rank in the German subsample in connection with both kindergarten $(3 ; 2.6 \%)$ and primary school learning $(2 ; 2.4 \%)$.

Looking at the bigger picture, we can see that in both subsamples "playfulness" is part of the central core in kindergarten learning. In addition, there are differences between elements of the central core and peripheral system in the two subsamples (Table 7, Table 8). While the German participants thought the social dimension was a core element, the Hungarian 
results also show the importance of active learning ("experience"). It is interesting, however, that in the Hungarian subsample, "playfulness" was a peripheral school-learning association.

\section{Conclusions and Limitations}

Once the lifelong learning approach has been set out in the framework strategies and goals set at the national and international level, it can be measured in education science. Consequently psychology, pedagogy and interdisciplinary research has been conducted on this topic. Germany - with its outstanding GLLI ranking (Kim, 2016) - and Hungary - with its moderate GLLI ranking (Kim, 2016) - were selected for the comparison in our study.

After comparing the two countries' framework strategies and the regulatory documents of the selected teacher training institutions, we collected data about the students' views on kindergarten and primary school learning using a qualitative association method with two groups of students $\left(\mathrm{N}_{\mathrm{G}}=14\right.$; $\mathrm{N}_{\mathrm{H}}=14$ ). The data analysis focused specifically on certain elements of the foundational phase of lifelong learning. This comparative study shows that there is a difference between the two countries, not just in the regulations, performance and school system, but also in the thinking of prospective kindergarten teachers.

Some of the results are similar to the most important recommendations of international regulatory documents and pedagogical, psychological models. Thus, "playfulness" can be interpreted as one of the main characteristics of learning and one of the main bases of learning motivation in the foundational phase. The kindergarten student teacher associations - together with the pedagogical psychological models - suggest that the acquisition of "basic" knowledge and skills prepares children not only for school but also for later life. In both subsamples the associations relating to "teamwork" and the "development of social competencies" focused on the development of social relationships and the promotion of social development.

It is also interesting to note that both the Hungarian and German kindergarten student teachers produced negative content and stereotypical associations in relation to school learning, deepening the contrast between the learning in the two types of institution (kindergarten/primary school).

In the Hungarian subsample there was a larger difference in the diversity values of the associations related to kindergarten versus school learning, 
while in the German subsample this difference was smaller. The rarity index shows that only the primary school related associations from the Hungarian subsample showed a larger difference from the others, which indicates that the Hungarian students provided multiple one-off associations relating to primary school learning. Given the differences in the education systems and the framework strategies for lifelong learning, one might have assumed that the comparative tables would show significantly larger differences than they in fact did. The greatest difference was not between the two subsamples, but in the assessment of the two education levels, which is a thought-provoking result when we consider how close the first grade of primary school is to kindergarten in terms of pupil age and time.

Although we cannot readily discern the secret of Germany's success in LLL, the lessons learned from this action research allow us to make the following assumptions or raise questions for further research:

A) According to the reviewed literature and regulatory documents:

a. Germany conducts more empirical education research on lifelong learning (Óhidy, 2012).

b. Germany has a stronger economy, which affects the effectiveness of LLL (Kim, 2016).

B) According to the training and output requirement documents:

a. The German document training and output requirements more closely reflect the country's strategic LLL framework (e.g. networking).

C) According to the results of the qualitative study:

a. In the German subsample, greater emphasis was placed on the social dimensions of learning

b. The skills and competencies necessary for lifelong learning were more prominent in the German subsample responses than the motivational elements were.

These differences have been revealed by a single comparison of some of the differences between the German and Hungarian documents and the views of the one group of kindergarten teacher students on LLL from the two countries.

This research shows that Germany is more successful in quantifiable, measurable dimensions; however, we found different kinds of elements in the views of Hungarian kindergarten student teachers that are known to be important for LLL (e.g. developing learning motivation) due to the practical 
basis of Hungarian teacher training. These elements cannot be measured by GLLI, yet these are essential for a successful future in individual's life.

Given that the present study only illustrates the views of one group of students from two institutions views on learning, the conclusions are not generalizable. In order to get a more complete picture of the views of prospective kindergarten teachers in the two countries, it would be worthwhile carrying out a representative large-scale study on this, ideally using the questionnaire method. In this research we have tried to point out the differences in LLL between the two countries by looking at a few aspects of one case. Nonetheless, this may provide a good basis for conducting more research in the future. Obtaining more comprehensive knowledge on the views of LLL among pedagogues in other countries could be a good starting point for moving towards educational practices that more consciously take LLL into account.

\section{Acknowledgement}

Supported by the UNKP-19-3-SZTE-293 New National Excellence Program of the Ministry for Innovation and Technology.

\section{References}

Aspin, D. N., \& Chapman, J. D. (2000). Lifelong learning: concepts and conceptions. International Journal of lifelong education, 19(1), 2-19.

Ben, J., Andrés, S. H., \& Steffen, K. (2012). TALIS The experience of new teachers results from TALIS 2008: Results from TALIS 2008. OECD publishing.

Bund-Länder Commission for Educational Planning and Research Promotion Secretariat (2004). Strategy for Lifelong Learning in the Federal Republic of Germany. Materials on educational planning and research promotion. 115. Bonn

Cosskun, Y. D., \& Demirel, M. (2010). Lifelong learning tendency scale: the study of validity and reliability. Procedia-Social and Behavioral Sciences, 5, 2343-2350.

Crick, R. D., Broadfoot, P., \& Claxton, G. (2004). Developing an effective lifelong learning inventory: The ELLI project. Assessment in Education: Principles, Policy \& Practice, 11(3), 247-272.

Delors, J. (1996). Learning: The treasure within-report to UNESCO of the International Commission. UNESCO.

Dudás, M. (2005). A tanárképzésbe belépő hallgatók nézeteinek feltárási lehetőségei. Pedagógusképzés, 3, 23-47.

Eckhardt, T. (2017). The education system in the Federal republic of Germany 2015/2016. A description of the responsibilities, structures and developments in education policy for the exchange of information in Europe. Eurydice, Bonn

European Commission (2017): Education And Training. Supporting education and 
training in Europe and beyond. Early childhood education and care. http://ec.europa.eu/education/policy/school/early-childhood_en

European Commission (2018): Proposal for a Council Recommendation on Key Competences for LifeLong Learning. Commission Staff Working Document, Accompanying the document. Brussels https://ec.europa.eu/education/sites/education/files/ swd-recommendation-key-competences-lifelong-learning.pdf

European Council (2000): Conclusions of the presidency, Lisbon http://www.europarl.europa.eu/summits/nice1_en.htm

Feng, L., \& Ha, J. L. (2016). Effects of teachers' information literacy on lifelong learning and school effectiveness. Eurasia Journal of Mathematics, Science \& Technology Education, 12(6), 1653-1663.

Finsterwald, M., Wagner, P., Schober, B., Lüftenegger, M., \& Spiel, C. (2013). Fostering lifelong learning-Evaluation of a teacher education program for professional teachers. Teaching and Teacher Education, 29, 144-155.

Günüç, S., Odabasi, H. F., \& Kuzu, A. (2014). Developing an effective lifelong learning scale (ELLS): Study of validity \& reliability. Egitim ve Bilim, 39(171).

Harangi László (2009). A „lifelong learning” paradigma és hatása a magyar közoktatásra. Magyar Pedagógiai Társaság Felnőttnevelési Szakosztály. OFI Tudástár. http:/ / ofi.hu/tudastar/tanulas-kora/lifelong-lear

Hercz, M. (2013). Motivated learning in positive school climate: "children's voice" about their school and learning. In: G. Czékus. (ed.) Motivation-Attention-Discipline.: 7th International Scientific Conference, Subotica, Serbia. pp. 460-475

Hursen, C. (2014). Are the teachers lifelong learners?. Procedia-Social and Behavioral Sciences, 116, 5036- 5040.

Hursen, C. (2016). A scale of lifelong learning attitudes of teachers: The development of LLLAS. Cypriot Journal of Educational Sciences, 11(1), 21-37.

Kim, J. Asia Pacific Educ. Rev. (2016) Development of a global lifelong learning index for future education 17: 439+463 https://doi.org/10.1007/s12564-016-9445-6 https://link.springer.com/article/10.1007/s12564-016-9445-6\#citeas

KKK (2016): 18/2016. (VIII. 5.) EMMI Decree 8/2013 on the training and output requirements of higher education vocational training, undergraduate and master's training, as well as on the common requirements for teacher training and the training and output requirements for each teacher profession. (I. 30.) [EMMI rendelet a felsőoktatási szakképzések, az alap-és mesterképzések képzési és kimeneti követelményeiröl, valamint a tanári felkészités közös követelményeiről és az egyes tanárszakok képzési és kimeneti követelményeiről szóló 8/2013. (I. 30.) EMMI rendelet módositásáról.] http://net.jogtar.hu/jr/gen/hjegy_doc.cgi?docid=A1600018. EMM\&timeshift=ffffff4\&txtreferer=00000001.TXT

Kirby, J. R., Knapper, C., Lamon, P., \& Egnatoff, W. J. (2010). Development of a scale to measure lifelong learning. International Journal of Lifelong Education, 29(3), 291-302.

Klug, J., Krause, N., Schober, B., Finsterwald, M., \& Spiel, C. (2014). How do teachers promote their students' lifelong learning in class? Development and first application of the LLL Interview. Teaching and Teacher Education, 37, 119-129.

Központi Statisztikai Hivatal [KSH] (2004): Az élethosszig tartó tanulás - lifelong learning, KSH Életszinvonal- és Emberierõforrás-statisztikai Főosztályának Kultúr- 
statisztikai osztálya, Budapest http://www.ksh.hu/docs/hun/xftp/idoszaki/pdf/ lifelong_learning.pdf

Kraiciné, Sz. M. (2004). Egész életen át tartó tanulás, Felnőttoktatás, Felsőoktatás - Kihívások az ezredfordulón. Filozófia-Müvelődés-történet, 253-271 http://old.tok. elte.hu/tarstud/filmuvtort_2004/szokoly.htm

Lüftenegger, M., Schober, B., van de Schoot, R., Wagner, P., Finsterwald, M., \& Spiel, C. (2012). Lifelong learning as a goal-Do autonomy and self-regulation in school result in well prepared pupils?. Learning and Instruction, 22(1), 27-36.

Majzik, L. (1997). Oktatás-rejtett kincs. Delors-jelentés a XXI. Századi oktatásról. Új Pedagógiai Szemle, 11, 3-17.

Maróti, A. (2002). Lehet-e tanulni egy életen át. Új pedagógiai szemle, 52, 7-8. p 3-17. http:/ / epa.oszk.hu/00000/00035/00062/2002-07-ta-Maroti-Lehet.html Nagy, J. (2003). Knowledge-Based Society and Education: The Problem of Time. Journal of Early Childhood Research, 1(1), 7-19.

OECD (1996). Lifelong learning for all: meeting of the Education Committee at Ministerial level, 16-17 January 1996. Paris: OECD. https://www.voced.edu.au/content/ ngv:25305

OECD (2007). Lifelong Learning and Human Capital. Policy Brief. http://www.forschungsnetzwerk.at/downloadpub/OECD-Letter-LLL.pdf

Óhidy, Andrea. (2012). Az élethosszig tartó tanulás paradigmája a német és a magyar oktatáspolitikában. Új Pedagógiai Szemle, 2, 5-22. https://folyoiratok.oh.gov. hu/uj-pedagogiai-szemle/az-elethosszig-tarto-tanulas-paradigmaja-a-nemet-es-a-magyar-oktataspolitikaban

Óhidy, Andrea. (2014). A Lifelong Learning-Paradigma a Németországi és a Magyarországi Neveléstudományi Vitában 1996-2005 Között. Magyar Pedagógia, 1, 3-23. http://www.magyarpedagogia.hu/document/1_Ohidy_MP1141.pdf

Ránki Lantos, Júlia. (2002). A tanulók motiválása az élethosszig tartó tanulásra. Új pedagógiai szemle, 10, 110-119. https://folyoiratok.oh.gov.hu/uj-pedagogiai-szemle/a-tanulok-motivalasa-az-elethosszig-tarto-tanulasra

Rittilun, S., Lawthong, N., \& Kanjanawasee, S. (2018). Construct validity of Thai lifelong learning inventory: Evidence from high-school students in Phrae, Kalasin, Prachin Buri, and Pangnga provinces. Kasetsart Journal of Social Sciences, 39(2), 207-214.

Sahin, M., Akbasli, S., \& Yelken, T. Y. (2010). Key competences for lifelong learning: The case of prospective teachers. Educational Research and Reviews, 5(10), 545-556. Sándor Mónika (2009): A versengés, a győzelem és a vesztés fogalma kisiskolás korban. Doktori disszertáció, Eötvös Loránd Tudományegyetem Pedagógiai És Pszichológiai Kar http://ppk.elte.hu/file/sandormonika_phd.pdf

Selcuk, G., Aydin, S., \& Cakmak, A. (2018). Examining beliefs of preservice teachers about self-competency and lifelong learning competency via Canonical Correlation Analysis. Cypriot Journal of Educational Sciences, 13(2), 474-486.

Takács, Nikolett. (2016). A pedagógus szakmai önreflexiójának szerepe énhatékonyságának alakulásában. Új Pedagógiai Szemle, 66, 5-6. https://folyoiratok.oh.gov. hu/uj-pedagogiai-szemle/a-pedagogus-szakmai-onreflexiojanak-szerepe-enhatekonysaganak-alakulasaban 
Tezer, M., \& Aynas, N. (2018). The effect of university education on lifelong learning tendency. Cypriot Journal of Educational Sciences, 13(1).

The Government of Hungary (2005) The strategy of the Government of the Republic of Hungary on lifelong learning [A Magyar Köztársaság Kormányának stratégiája az egész életen át tartó tanulásról] (2005): http://www.nefmi.gov.hu/download.php?docID $=415$

The Government of Hungary (2014) Framework strategy for lifelong learning policy for the period 2014/2020 [Az egész életen át tartó tanulás szakpolitikájának keretstratégiája a 2014/2020 közötti időszakra.] http://www.kormany.hu/download/7/ fe/20000/Eg\%C3\%A9sz\%20\%C3\%A9leten\%20\%C3\%A1t\%20tart\%C3\%B3\%20tanul\%C3\%A1s.pdf

Uzunboylu, H., \& Hürsen, Ç. (2011). Lifelong Learning Competence Scale (LLLCS): The study of validity and reliability. Hacettepe Üniversitesi Eğitim Fakültesi Dergisi, 41(41), 449-460.

\section{Author:}

Nikolett Flick-Takács, Ph.D. student

University of Szeged

Doctoral School of Education

Szeged

Hungary

Email: takacsnikolett@edu.u-szeged.hu 